Article

\title{
Tax Regulation on Blockchain and Cryptocurrency: The Implications for Open Innovation
}

\author{
Andrea Peláez-Repiso ${ }^{1,2}$ (D) Pablo Sánchez-Núñez ${ }^{2,3,4, *(\mathbb{D})}$ and Yolanda García Calvente 1 \\ 1 Department of Financial and Tax Law, Faculty of Law, Universidad de Málaga, 29071 Malaga, Spain; \\ andreapelaezr@uma.es (A.P.-R.); yolanda@uma.es (Y.G.C.) \\ 2 Center for Applied Social Research (CISA), Ada Byron Research Building, Universidad de Málaga, \\ 29071 Malaga, Spain \\ 3 Department of Audiovisual Communication and Advertising, Faculty of Communication Sciences, \\ Universidad de Málaga, 29071 Malaga, Spain \\ 4 Instituto de Investigación Biomédica de Málaga (IBIMA), 29010 Malaga, Spain \\ * Correspondence: psancheznunez@uma.es
}

\section{check for}

updates

Citation: Peláez-Repiso, A.; Sánchez-Núñez, P.; García Calvente, Y. Tax Regulation on Blockchain and Cryptocurrency: The Implications for Open Innovation. J. Open Innov.

Technol. Mark. Complex. 2021, 7, 98. https://doi.org/10.3390/joitmc7010098

Received: 9 February 2021

Accepted: 5 March 2021

Published: 16 March 2021

Publisher's Note: MDPI stays neutral with regard to jurisdictional claims in published maps and institutional affiliations.

Copyright: (c) 2021 by the authors. Licensee MDPI, Basel, Switzerland. This article is an open access article distributed under the terms and conditions of the Creative Commons Attribution (CC BY) license (https:// creativecommons.org/licenses/by/ $4.0 /)$.

\begin{abstract}
Blockchain is a technology that will change the relationships between the different actors in society, individuals, companies and administration, in aspects as important as taxation, by implementing concepts such as Self-sovereign identity (SSI) and Smart Contracts; which support, for example, virtual currencies, that are not controlled by any state, financial institution or centralized company. Hence, the growing interest of researchers, investors, traders, marketers, enterprises, and administrations to know the scope of this new technology and its tax implications. The main objective of this work is to clarify the status of these studies, explore issues, methods, findings, and trends as well as to define their meaning within the current research scenario. To achieve these objectives, bibliometric analysis was carried out, retrieving 349 research papers, and analyzing 343 papers published between 2015-2019 based on the results of the Web of Science (WoS).
\end{abstract}

Keywords: informetrics; scientometrics; science mapping analysis; bibliometrix; virtual currencies; virtual money; legal; financial law; financial markets; e-commerce

\section{Introduction}

Technological development has contributed decisively to the transformation of the economy and the progress of humanity. Blockchain is one of the technological innovations that present great potential for this progress since it is changing how economic transactions are carried out [1].

Created by Satoshi Nakamoto in 2008, its initial application was linked to the cryptocurrency "Bitcoin, A peer to peer Electronic Cash system", a peer-to-peer system, through which transactions with crypto-currencies could be executed safely, without having to worry about their authenticity, or if they are spent more than once (double spending) [2]. Since then, this technology has been evolving and is currently being applied to new types of crypto money such as Ethereum, Ripple, EOS, or Litecoin; as well as in different sectors of society [3]. In addition, the development of blockchain technology and the incorporation in the financial markets of a vast offer of crypto-currencies and virtual money has led to the creation, expansion, and internationalization of neo-banks, Challenger Banks, BaaS or Fintech, for example, Revolut, N26, Monzo, PayPal Commerce Platform or TransferWise, among others $[4,5]$.

Blockchain is defined as a database formed by a decentralized network, distributed and immutable, through which transactions can be made safely, without the need for intermediaries and leaving an incorruptible record [6].

New concepts are emerging around blockchain technology that challenges any traditional approach, such as Self-sovereign identity (SSI) or Smart Contracts [7,8]), and so forth: 
- Self-sovereign identity (SSI) is based on portable personal repositories where citizens have full control of their data, and where they can store and manage their private keys, authenticators, tokens such as cryptocurrencies, and digital credentials, securely and reliably through a cryptographic process [9].

- Smart Contracts is a new type of self-executing contract based on computer protocols that are designed to automatically facilitate, verify and enforce the negotiation, execution of contracts or flows of digital assets, such as cryptocurrencies [10-12], without central authorities [13].

Although we are in the initial stages of implementation, the interest in this new technology by companies, organizations, and individuals has been growing due to the benefits it can bring: transparency, all those involved have access to consulting the information; security [14], modifications to the information can only be made by those who are authorized; cost reduction, by eliminating intermediaries; the possibility of carrying out transactions through Smart Contracts [15]; open innovation, facilitating new forms of relationship between different actors in society [16-18].

However, this interest is not only from organizations, in fact, in the scientific community this interest has been increasing in recent years, raising a wide spectrum of research about possible application scenarios in the digital economy and smart industries, including financial services $[19,20]$.

Nonetheless, the speed at which new technologies are generated and implemented in today's information and communication society diverges from the speed of legislators in passing new laws to regulate and protect citizens from these new realities. Blockchain is not alien to this situation and poses legal challenges such as the lack of an owner, the limits of the registration function that they develop, data protection, some aspects about the identity of the participants, or the characterization of crypto-currencies and their relationship with taxes or legal money, among others [21].

Due to the great interest of society in this new technology, as well as the gap between technological advances, implementation, and legislation, it is necessary to have studies that clarify the main issues related to this new technology and its application [22]. At present, no study reflects the research recently carried out in this field.

Therefore, the main objective of this work is to analyze the main actors that address research related to the regulation taxation of blockchain, crypto money, and Smart Contracts by using the methodology of bibliometric analysis. Bibliometrics is a part of scientometrics that applies mathematical and statistical methods to all scientific literature and the authors who produce it, intending to study and analyze scientific activity [23-29].

This review aims to answer the following research questions:

$>$ RQ1. Which are the most relevant sources, most local cited sources, authors, author's affiliations, corresponding author's, country scientific production and most cited countries in the research on tax regulation in the development of blockchain and cryptocurrencies?

$>$ RQ2. Which are the most global documents, and thematic and conceptual structure related to research on tax regulation in the development of blockchain and cryptocurrencies?

$>$ RQ3. Which is the scientific and academic social structure researching the regulation of taxation in the development of blockchain and cryptocurrencies?

The work has been organized as follows: Section 2 shows the materials, the methodological approach, and the design of the Web of Science search equation; Section 3 exposes the results of the bibliometric analysis on taxation regulation of blockchain and cryptocurrencies; and finally, Section 4 contains the discussion, conclusions and the main future lines of research.

\section{Materials and Methods}

\subsection{Database, Data Acquisition, and Querying}

The Web of Science (WoS) database was used as a source to perform the bibliometric analysis. Web of Science is a platform owned by Clarivate Analytics, consisting of a 
large collection of bibliographic databases, citations, and references from scientific publications in any discipline of knowledge, in science, technology, social sciences, arts, and humanities [30,31].

The search equation comprised of a set of key terms (title, abstract, or keywords) related to virtual currency, blockchain development, tax regulation, as well as legal issues or financial markets, among others (Table 1). The period of analysis was 2015-2019, these last five years being the most recent and with the highest scientific production. No exclusion criteria were established related to the language of the published document or the document type (conference proceedings, article, or book, etc.).

Table 1. Search query design.

\begin{tabular}{|c|c|c|c|c|}
\hline Indexes & Timespan & Search & Results & Download \\
\hline $\begin{array}{l}\text { SCI-EXPANDED, SSCI, } \\
\text { A\&HCI, CPCI-S, } \\
\text { CPCI-SSH, BKCI-S, } \\
\text { BKCI-SSH, ESCI, } \\
\text { CCR-EXPANDED, IC. }\end{array}$ & 2015-2019 & $\begin{array}{c}(\mathrm{TS}=((\text { ("Blockchain" OR } \\
\text { "Cryptocurrenc*" OR “Virtual } \\
\text { Currenc*" OR “Virtual Money") AND } \\
\text { ("Financial Law" OR “Legal" OR } \\
\text { "Taxation *" OR “Tax system"))) }\end{array}$ & 349 & 26 October 2020 \\
\hline
\end{tabular}

\subsection{Data Filtering and Data Availability}

349 works on taxation regulation in the development of blockchain and crypto money were retrieved from the Web of Science (2015-2019). Of these, the software R Package Bibliometrix [32] recognizes and analyzes 343 works published during the period 2015-2019.

The WoS database registers 6 additional papers (a sum of 349) that have been accepted and possibly published as a preprint in the last year of this study (2019). The final publication date for these papers is 2020, so they would be excluded from the present study. The inclusion of these works in the present research, despite belonging to the same period defined in the search equation, could distort the interpretation of the data and the development of the analysis because it does not belong to the calendar year of the period covered by the review.

Citation Report and WoS Dataset used in the present study may be founded in the Zenodo Repository [33].

\subsection{Bibliometric Analysis Tool: Bibliometrix (R Package)}

R Package Bibliometrix [32] is a set of open-source tools for quantitative research in scientometrics and bibliometrics that includes all the main bibliometric methods of analysis. Bibliometrix allows us to highlight the most relevant documents, journals, countries, authors, institutions, as well as study and visualize the different research collaboration networks established or emerging trends in a specific area of knowledge. Several studies have been carried out using R Package Bibliometrix. Some examples have been works done in the field of social research and data science [34], the Internet of Things (IoT) logistics [35], biology [36], or artificial intelligence research [37], among others.

\section{Results}

\subsection{Main Information about the Collection}

Table 2 describes the main results of the analysis: document type, document content, and author collaboration. The study comprises the period of 2015-2019, yielding a total of 343 documents, with an average of 4437 citations/document, an average of 1,41 citation document/year, and a total of 11,509 references. 
Table 2. Main information about the study data.

\begin{tabular}{|c|c|}
\hline Description & Results \\
\hline \multicolumn{2}{|l|}{ Main information about the study data } \\
\hline Timespan & 2015:2019 \\
\hline Sources (Journals, Books, etc.) & 252 \\
\hline Documents & 343 \\
\hline Average years from publication & 1.76 \\
\hline Average citations per documents & 4.437 \\
\hline Average citations per year per doc & 1.41 \\
\hline References & 11,509 \\
\hline \multicolumn{2}{|l|}{ Document types } \\
\hline Article & 193 \\
\hline Article; book chapter & 14 \\
\hline Article; proceedings paper & 2 \\
\hline Book review & 2 \\
\hline Editorial material & 5 \\
\hline Proceedings paper & 118 \\
\hline Review & 9 \\
\hline \multicolumn{2}{|l|}{ Document contents } \\
\hline Keywords Plus (ID) & 193 \\
\hline Author's Keywords (DE) & 905 \\
\hline \multicolumn{2}{|l|}{ AUTHORS } \\
\hline Authors & 767 \\
\hline Author Appearances & 801 \\
\hline Authors of single-authored documents & 126 \\
\hline Authors of multi-authored documents & 641 \\
\hline \multicolumn{2}{|l|}{ AUTHORS COLLABORATION } \\
\hline Single-authored documents & 132 \\
\hline Documents per author & 0.447 \\
\hline Authors per document & 2.24 \\
\hline Co-Authors per documents & 2.34 \\
\hline Collaboration index & 3.04 \\
\hline
\end{tabular}

The study has shown that articles in scientific journals (193) and communications in conferences/congresses (118) are the document types preferred.

A total of 905 keywords have been used in all the works that make up the study sample. It should be noted that there is a high proportion of individual authors in this type of publication. Of the 349 works recovered, 132 have been written by a single author.

\subsection{Annual Scientific Production}

Figure 1 shows the annual production volume (2015-2019) of research on tax regulation in blockchain and crypto money. The research in this area has experimented with exponential growth of $116.88 \%$. In ascending order: 2015 (with 8 articles published), 2016 (15 articles), 2017 (42 articles), 2018 (101 articles), and 2019 (177 articles).

\subsection{Most Relevant Sources}

Table 3 shows the most relevant academic-scientific sources on blockchain tax regulation and crypto-currency development. Within the Top 5 we find in 1st position the COMPUTER LAW AND SECURITY REVIEW with 15 published articles; followed in 2nd position by the JOURNAL EUROPEAN REVIEW OF PRIVATE LAW with 7 studies; in 3rd position the BALTIC JOURNAL OF ECONOMIC STUDIES with 6 studies; in 4th position the RUSSIAN JOURNAL OF CRIMINOLOGY with 5 studies; and in 5th position the UBIQUITOUS COMPUTING AND THE INTERNET OF THINGS with 5 published studies. SCImago Journal Rank (SJR) and Journal Citation Reports (JCR) categories and quartiles of 
the resulting sources were identified. From the selection of sources, we found that only one source (COMPUTER LAW\&SECURITY REVIEW (CL\&SR)) is included in the JCR.) However, four sources are included in SJR (in this case, CL\&SR, RUSSIAN JOURNAL OF CRIMINOLOGY, UNIFORM LAW REVIEW and BRICS LAW JOURNAL). The sources belong to the following categories: Business, Management, and Accounting; Computer Networks and Communications; Law; and Sociology and Political Science.

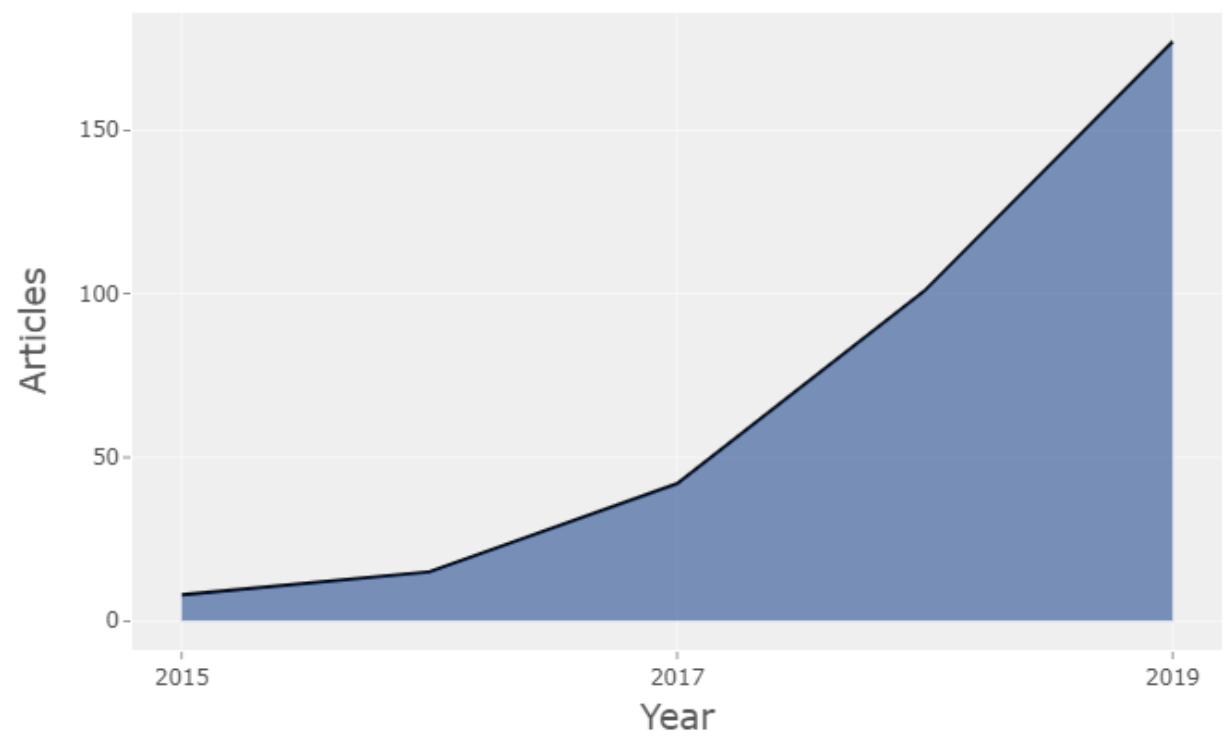

Figure 1. Annual Scientific Production (2015-2019).

Table 3. Top 10 Most relevant sources (2015-2019).

\begin{tabular}{|c|c|c|c|c|}
\hline Rank & Sources & SJR Category and Quartile & JCR Category and Quartile & Articles \\
\hline 1. & $\begin{array}{l}\text { COMPUTER LAW \& } \\
\text { SECURITY REVIEW }\end{array}$ & $\begin{array}{l}\text { BUSINESS, MANAGEMENT } \\
\text { AND ACCOUNTING } \\
\text { (MISCELLANEOUS), } \\
\text { COMPUTER NETWORKS } \\
\text { AND COMMUNICATIONS, } \\
\text { AND LAW; Q1 (2019) }\end{array}$ & LAW; Q1 (2019) & 15 \\
\hline 2. & $\begin{array}{l}\text { EUROPEAN REVIEW OF } \\
\text { PRIVATE LAW }\end{array}$ & - & - & 7 \\
\hline 3. & $\begin{array}{l}\text { BALTIC JOURNAL OF } \\
\text { ECONOMIC STUDIES }\end{array}$ & - & - & 6 \\
\hline 4. & $\begin{array}{l}\text { RUSSIAN JOURNAL OF } \\
\text { CRIMINOLOGY }\end{array}$ & $\begin{array}{c}\text { LAW; Q2 (2019), SOCIOLOGY } \\
\text { AND POLITICAL SCIENCE; } \\
\text { Q3 (2019) }\end{array}$ & - & 5 \\
\hline 5. & $\begin{array}{c}\text { UBIQUITOUS COMPUTING } \\
\text { AND THE INTERNET OF } \\
\text { THINGS: PREREQUISITES FOR } \\
\text { THE DEVELOPMENT OF ICT }\end{array}$ & 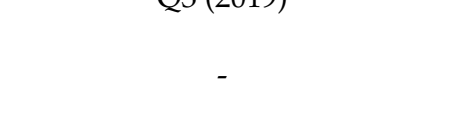 & - & 5 \\
\hline 6. & $\begin{array}{l}\text { AMAZONIA INVESTIGA } \\
\text { PROCEEDINGS OF THE 1ST }\end{array}$ & - & - & 4 \\
\hline 7. & $\begin{array}{l}\text { INTERNATIONAL SCIENTIFIC } \\
\text { CONFERENCE MODERN } \\
\text { MANAGEMENT TRENDS AND } \\
\text { THE DIGITAL ECONOMY: FROM } \\
\text { REGIONAL DEVELOPMENT TO } \\
\text { GLOBAL ECONOMIC GROWTH } \\
\text { (MTDE 2019) }\end{array}$ & 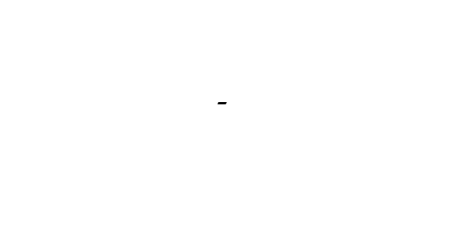 & - & 4 \\
\hline 8. & $\begin{array}{l}\text { UNIFORM LAW REVIEW } \\
\text { BITCOIN AND MOBILE }\end{array}$ & LAW; Q3 (2019) & - & 4 \\
\hline 9. & $\begin{array}{c}\text { PAYMENTS: CONSTRUCTING A } \\
\text { EUROPEAN UNION } \\
\text { FRAMEWORK }\end{array}$ & - & - & 3 \\
\hline 10. & BRICS LAW JOURNAL & LAW; Q3 (2019) & - & 3 \\
\hline
\end{tabular}




\subsection{Most Local Cited Sources (from Reference Lists)}

Table 4 shows the times that a document or source included in this collection has been cited by other authors in the collection as well. Within the Top 5, we find in 1st position we find the LECTURE NOTES COMPUTER SCIENCE appearing in 124 research papers, followed in 2nd position by the BITCOIN PEER TO PEER (112 papers), in 3rd position the FORBES (69 papers), in 4th position the IEEE ACCESS (51 papers), and finally in 5th position the JOURNAL OF MEDICAL SYSTEMS with 49 papers.

Table 4. Top 10 most local cited sources (from reference lists) during 2015-2019.

\begin{tabular}{ccc}
\hline Rank & Sources & Articles \\
\hline 1. & LECTURE NOTES COMPUTER SCIENCE & 124 \\
2. & BITCOIN PEER TO PEER & 112 \\
3. & FORBES & 69 \\
4. & IEEE ACCESS & 51 \\
5. & JOURNAL OF MEDICAL SYSTEMS & 49 \\
6. & COMMUNICATIONS OF THE ACM & 42 \\
7. & THESIS & 42 \\
8. & COMPUTER LAW \& SECURITY REVIEW & 37 \\
9. & FINANCIAL TIMES & 34 \\
10. & BLOCKCHAIN REVOLUTION & 33 \\
\hline
\end{tabular}

\subsection{Source Local Impact (H-Index)}

Table 5 shows the scientific journals with the highest impact, using the H-Index as an impact comparative parameter [38]. The journals with the highest impact coincide with Table 3, which showed the journals with the highest number of studies published on blockchain tax regulation and the development of cryptocurrencies. Within the Top 5, In ascending order by the number of publications, we find the journal COMPUTER LAW AND SECURITY REVIEW, the 1st one of the ranking, with an H-Index of 7, which means that the journal has 7 studies that have been cited at least 7 times, a total of 193 citations and 15 publications (starting with publications of the mentioned subject in the year 2017), followed in 2nd position by the EUROPEAN REVIEW OF PRIVATE LAW (2 H-Index, 10 citations and 7 documents), in 3rd position the BALTIC JOURNAL OF ECONOMIC STUDIES (also 2 H-Index, 12 citations and 6 documents), in 4th position the RUSSIAN JOURNAL OF CRIMINOLOGY (1 H-Index, 3 citations and 5 documents), and finally in 5th position the UBIQUITOUS COMPUTING AND THE INTERNET OF THINGS: PREREQUISITES FOR THE DEVELOPMENT OF ICT (0 H-Index, 0 citations and 5 documents).

Table 5. Top 10 sources' local impact (H-Index) during 2015-2019. TC (Total Citations), NP (Number of Publications), and PY (Publication Year Start).

\begin{tabular}{|c|c|c|c|c|c|}
\hline Rank & Source & H-Index & TC & NP & PY Start \\
\hline 1. & COMPUTER LAW \& \& SECURITY REVIEW & 7 & 193 & 15 & 2017 \\
\hline 2. & EUROPEAN REVIEW OF PRIVATE LAW & 2 & 10 & 7 & 2017 \\
\hline 3. & BALTIC JOURNAL OF ECONOMIC STUDIES & 2 & 12 & 6 & 2017 \\
\hline 4. & RUSSIAN JOURNAL OF CRIMINOLOGY & 1 & 3 & 5 & 2018 \\
\hline 5. & UBIQUITOUS COMPUTING AND THE INTERNET OF & 0 & 0 & 5 & 2019 \\
\hline 6. & $\begin{array}{l}\text { AMAZONIA INVESTIGA } \\
\text { PROCEEDINGS OF THE 1ST INTERNATIONAL SCIENTIFIC }\end{array}$ & 1 & 1 & 4 & 2019 \\
\hline 7. & $\begin{array}{l}\text { CONFERENCE MODERN MANAGEMENT TRENDS AND THE } \\
\text { DIGITAL ECONOMY: FROM REGIONAL DEVELOPMENT TO } \\
\text { GLOBAL ECONOMIC GROWTH (MTDE 2019) }\end{array}$ & 0 & 0 & 4 & 2019 \\
\hline 8. & UNIFORM LAW REVIEW & 1 & 5 & 4 & 2016 \\
\hline 9. & $\begin{array}{c}\text { BITCOIN AND MOBILE PAYMENTS: CONSTRUCTING A } \\
\text { EUROPEAN UNION FRAMEWORK }\end{array}$ & 1 & 3 & 3 & 2016 \\
\hline 10. & BRICS LAW JOURNAL & 2 & 8 & 3 & 2018 \\
\hline
\end{tabular}




\subsection{Authors' Local Impact}

Table 6 shows the impact of authorship. Within the Top 3, we find the author SAVELYEV A has published 3 scientific works related to tax regulation in cryptocurrencies and the development of blockchain and these three works have received a minimum of 3 citations, so it has an H-Index of 3 and a total number of citations of 89. It is followed by the authors DROZD O and GOVERNATORI G, both with an H-Index of 2.

Table 6. Top 10 authors' local impact during 2015-2019. TC (Total Citations), NP (Number of Publications), and PY (Publication Year Start).

\begin{tabular}{cccccc}
\hline Rank & Author & H-Index & TC & NP & PY_Start \\
\hline 1. & SAVELYEV A & 3 & 89 & 3 & 2017 \\
2. & DROZD O & 2 & 10 & 3 & 2017 \\
3. & GOVERNATORI G & 2 & 65 & 2 & 2016 \\
4. & HACKER P & 2 & 17 & 2 & 2017 \\
5. & IDELBERGER F & 2 & 65 & 2 & 2016 \\
6. & KIM S & 2 & 19 & 2 & 2017 \\
7. & OUYANG L & 2 & 62 & 2 & 2019 \\
8. & SINGH M & 2 & 19 & 2 & 2017 \\
9. & UBACHT J & 2 & 13 & 2 & 2018 \\
10. & WANG FY & 2 & 62 & 2 & 2019 \\
\hline
\end{tabular}

\subsection{Most Relevant Affiliations}

Table 7 shows the classification of scientific production by author's affiliation. Two university rankings are used for comparison: the 2019 Quacquarelli Symonds (QS) World University Rankings and the 2019 Academic Ranking of World Universities (ARWU) [39].

Table 7. Top 10 most relevant authors' affiliations during 2015-2019.

\begin{tabular}{|c|c|c|c|c|c|}
\hline Rank & Affiliations & Country & Affiliation (Freq.) & QS 2019 & ARWU 2019 \\
\hline 1. & $\begin{array}{l}\text { THE INSTITUTE OF } \\
\text { LEGISLATION AND } \\
\text { COMPARATIVE LAW }\end{array}$ & RUSSIA & 10 & - & - \\
\hline 2. & $\begin{array}{l}\text { NATIONAL ACADEMY OF } \\
\text { INTERNAL AFFAIRS } \\
\text { THE RESEARCH INSTITUTE }\end{array}$ & UKRAINE & 9 & - & - \\
\hline 3. & $\begin{array}{l}\text { OF INDUSTRIAL } \\
\text { ECONOMICS }\end{array}$ & SWEDEN & 7 & - & - \\
\hline 4. & $\begin{array}{c}\text { SWINBURNE UNIVERSITY OF } \\
\text { TECHNOLOGY }\end{array}$ & AUSTRALIA & 7 & 387 & $301-400$ \\
\hline 5. & $\begin{array}{c}\text { THE TALLINN UNIVERSITY } \\
\text { OF TECHNOLOGY }\end{array}$ & ESTONIA & 7 & $601-650$ & - \\
\hline 6. & $\begin{array}{l}\text { URAL STATE UNIVERSITY OF } \\
\text { ECONOMICS }\end{array}$ & RUSSIA & 7 & 412 & $701-800$ \\
\hline 7. & $\begin{array}{c}\text { VOLGOGRAD STATE } \\
\text { UNIVERSITY }\end{array}$ & RUSSIA & 7 & - & - \\
\hline 8. & $\begin{array}{c}\text { CHINESE UNIVERSITY OF } \\
\text { HONG KONG }\end{array}$ & HONG KONG & 6 & 49 & $101-150$ \\
\hline 9. & $\begin{array}{c}\text { THE DELFT UNIVERSITY } \\
\text { TECHNOLOGY }\end{array}$ & NETHERLANDS & 6 & $151-200$ & 52 \\
\hline 10. & $\begin{array}{l}\text { KAZAN FEDERAL } \\
\text { UNIVERSITY }\end{array}$ & RUSSIA & 6 & 439 & $801-900$ \\
\hline
\end{tabular}

We can highlight, in order of participation: THE INSTITUTE OF LEGISLATION AND COMPARATIVE LAW (RUSSIA), followed in 2nd position by the NATIONAL ACADEMY OF INTERNAL AFFAIRS (UKRAINE), in 3rd position THE RESEARCH INSTITUTE OF INDUSTRIAL ECONOMICS (SWEDEN), in 4th position the SWINBURNE UNIVERSITY 
OF TECHNOLOGY (AUSTRALIA), in 5th position THE TALLINN UNIVERSITY OF TECHNOLOGY (ESTONIA), in 6th position the URAL STATE UNIVERSITY OF ECONOMICS (RUSSIA), in 7th position the VOLGOGRAD STATE UNIVERSITY (RUSSIA), in 8th position the CHINESE UNIVERSITY OF HONG KONG (HONG KONG), in 9th position THE DELFT UNIVERSITY TECHNOLOGY (THE NETHERLANDS), and finally in 10th position the KAZAN FEDERAL UNIVERSITY (RUSSIA).

The results reveal that within this classification of influential affiliations, $40 \%$ of them belong to the Russian Federation. The most productive organizations in research on tax legislation in blockchain and cryptocurrency are not part of either of the two international rankings of quality and university evaluation ARWU and QS (1st to 3rd position) and only the universities of HONG KONG (8th position) and THE NETHERLANDS (9th position) stand out with relevant positions in the international university rankings.

\subsection{Corresponding Authors' Countries}

Figure 2 and Table 8 shows the country of the corresponding authors. The corresponding author is the author who sends the article to the journal editor and channels all correspondence with him; also, his e-mail address usually appears on the first page of the article, acting as a contact author with other interested researchers [40]. Within the Top 3 we find in the 1st place Russia, which has published a total of 50 papers where the corresponding author was a Russia-based researcher, followed in 2nd position by the USA with 41 published papers with 41 corresponding America-based authors, and in 3rd position the United Kingdom with 25 papers and 25 UK-based corresponding authors. The ones with the highest rates of international collaboration are the USA, UK, Germany, and China. However, Russia being the first country in volume of correspondence authors, strangely does not have many international collaborations; the same happens with Ukraine, with a lot of scientific production and no intra-collaboration.

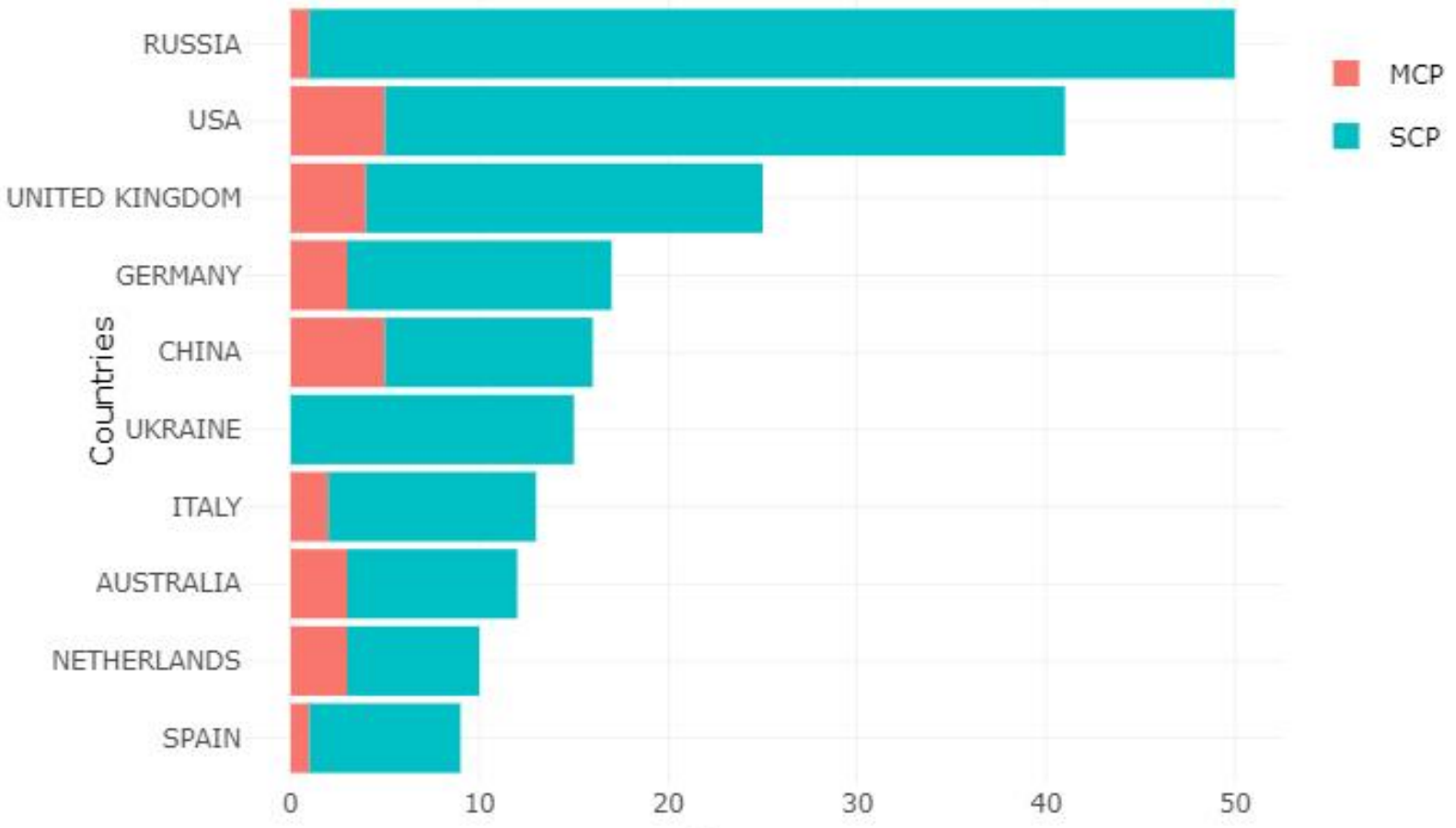

$\mathrm{N}$. of Documents

Figure 2. Corresponding author's country. Intra-country (SCP) and inter-country (MCP) collaboration during 2015-2019. 
Table 8. The intra-country (SCP) and inter-country (MCP) collaboration indices during 2015-2019.

\begin{tabular}{cccccc}
\hline Rank & Country & Articles & Freq. & SCP & MCP \\
\hline 1. & RUSSIA & 50 & 0.14749 & 49 & 1 \\
2. & USA & 41 & 0.12094 & 36 & 5 \\
3. & UNITED & 25 & 0.07375 & 21 & 4 \\
4. & KINGDOM & 17 & 0.05015 & 14 & 3 \\
5. & GERMANY & 17 & 0.0472 & 11 & 5 \\
6. & CHINA & 16 & 0.04425 & 15 & 0 \\
7. & UKRAINE & 15 & 0.03835 & 11 & 2 \\
8. & ITALY & 13 & 0.0354 & 9 & 3 \\
9. & NESTRALIA & 12 & 0.0295 & 7 & 3 \\
10. & SPAIN & 9 & 0.02655 & 8 & 1 \\
\hline
\end{tabular}

\subsection{Country Scientific Production}

Figure 3 and Table 9 shows the distribution of scientific production frequencies worldwide by the affiliation country. Within the Top 5 , we appreciate how RUSSIA in 1st position (159 freq.) and the USA in 2nd position (115 freq.) stands out on the hegemony of academicscientific production, followed in the 3rd position by the UK (freq.), in 4th position CHINA (62 freq.) and 5th position UKRAINE (51 freq.).

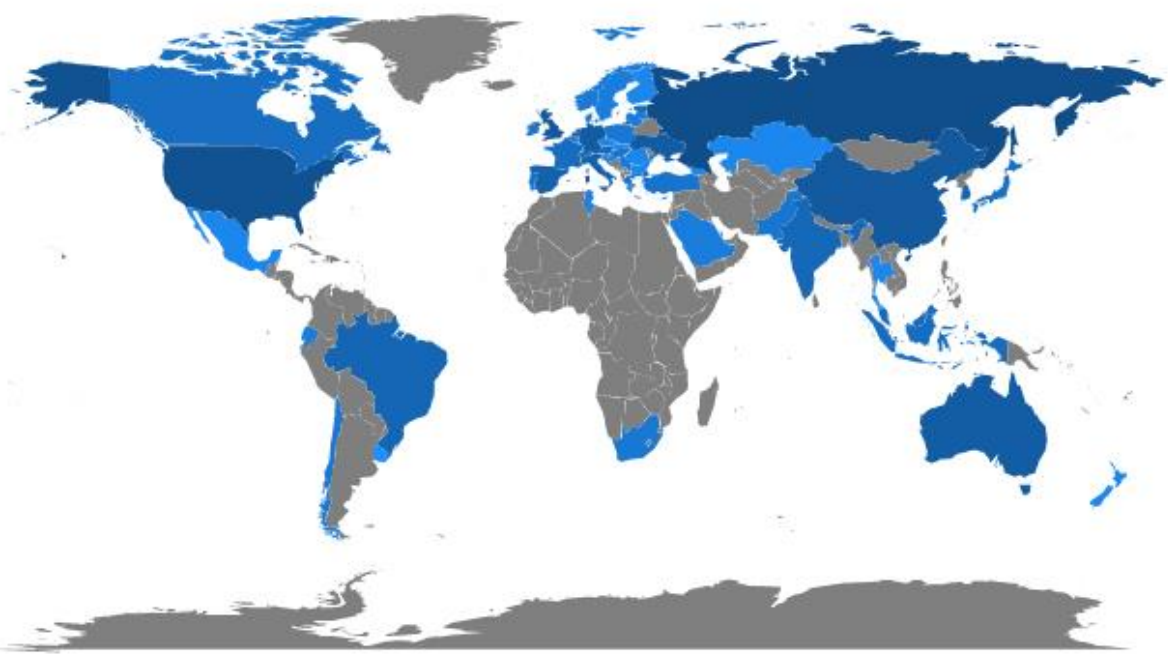

Figure 3. Countries' scientific production (2015-2019).

Table 9. Top 10 countries' scientific production during 2015-2019 (Freq.).

\begin{tabular}{ccc}
\hline Rank & Country & Freq. \\
\hline 1. & RUSSIA & 159 \\
2. & USA & 115 \\
3. & UK & 80 \\
4. & CHINA & 62 \\
5. & UKRAINE & 51 \\
6. & GERMANY & 50 \\
7. & AUSTRALIA & 49 \\
8. & ITALY & 35 \\
9. & SPAIN & 32 \\
10. & NETHERLANDS & 31 \\
\hline
\end{tabular}




\subsection{Most Cited Countries}

Table 10 shows the total number of citations received by the different countries in the selected study sample. In descending order, we find within the Top 3, in the 1st position the USA, being the first preference by authors when it comes to reference works in the selection made of 343 documents (with a total number of citations of 388 and average of 9.43). In 2nd position, we find that CHINA was the second option for authors to cite references in their works (reaching a total of 180 citations and an average of 11.25). Finally, in 3rd place, we find the UK (with a total of 129 citations and an average of 5.16).

Table 10. Top 10 most cited countries (2015-2019). Total Citations (TC) and Average Article Citations (AAC).

\begin{tabular}{cccc}
\hline Rank & Country & TC & AAC \\
\hline 1. & USA & 388 & 9.463 \\
2. & CHINA & 180 & 11.25 \\
3. & UNITED KINGDOM & 129 & 5.16 \\
4. & RUSSIA & 124 & 2.48 \\
5. & ITALY & 109 & 8.385 \\
6. & AUSTRALIA & 88 & 7.333 \\
7. & SLOVENIA & 43 & 21.5 \\
8. & QATAR & 38 & 38 \\
9. & NETHERLANDS & 35 & 3.5 \\
10. & SPAIN & 35 & 3.889 \\
\hline
\end{tabular}

\subsection{Most Global Cited Documents}

Table 11 shows the selection of the most cited articles in taxation regulation on blockchain and cryptocurrencies.

Table 11. Top 10 most global cited documents. Total Citations (TC) and Total Citation per Year (TCpY).

\begin{tabular}{ccccc}
\hline Rank & Paper & Reference & TC & TCpY \\
\hline 1. & KSHETRI N, 2017, TELECOMMUN POLICY & {$[14]$} & 104 & 26 \\
2. & KIVIAT TI, 2015, DUKE LAW J & {$[41]$} & 63 & 10.5 \\
3. & ZHAO JL, 2016, FINANC INNOV & {$[20]$} & 61 & 12.2 \\
4. & WANG S, 2019, IEEE TRANS SYST MAN CYBERN -SYST & {$[13]$} & 59 & 29.5 \\
5. & WERBACH K, 2017, DUKE LAW J & {$[42]$} & 51 & 12.75 \\
6. & SULLIVAN C, 2017, COMPUT LAW SECUR REV & {$[9]$} & 49 & 12.25 \\
7. & SAVELYEV A, 2018, COMPUT LAW SECUR REV & {$[43]$} & 46 & 15.333 \\
8. & TURK Z, 2017, CREATIVE CONSTRUCTION & {$[44]$} & 43 & 10.75 \\
9. & CONFERENCE 2017, CCC 2017 & & \\
10. & IDELBERGER F, 2016, RULE TECHNOLOGIES: RESEARCH, & {$[45]$} & 39 & 7.8 \\
& TOOLS, AND APPLICATIONS & {$[46]$} & 38 & 12.667 \\
\hline
\end{tabular}

Within the Top 3, in total citation descending order, we find in the 1st place the work of KSHETRI N [14] entitled "Blockchain's roles in strengthening cybersecurity and protecting privacy". The article provides a comprehensive analysis and explanation of blockchain's roles in tracking the sources of insecurity in supply chains related to IoT devices and delves into how blockchain can make it possible to contain an IoT security breach in a targeted way after it is revealed.

In the 2nd position, we find the work of KIVIAT TI [41] entitled "Beyond Bitcoin: Issues in Regulating Blockchain Transactions". The work examines the application of blockchain in the financial sector, through the use of virtual currencies, such as Bitcoin, addressing its characteristics and the possibility of making transactions more efficiently, without the need for a central institution and under the control of each user. In addition, the work raises several questions regarding the legal regulation of these transactions. 
By the end, in the 3rd position, we find the work of ZHAO JL et al. [20] entitled "Overview of business innovations and research opportunities in Blockchain and introduction to the special issue". The authors give an overview of blockchain research and development by showing that blockchain has enabled Bitcoin, the most successful digital currency, and its widespread adoption in finance and analyses how other business sectors will empower many business innovations as well as many research opportunities.

\subsection{Keyword Plus TreeMap}

The terminology associated with tax regulation in the development of blockchain and crypto-currency taxes can be seen in Figure 4. We found that some of the most frequent terms are blockchain (freq. 9), internet (freq. 7), law (freq. 7) technology (freq. 6), or trust (freq. 6). The terms that have been used to a lesser extent have been access-control (freq. 2) or distributed ledger technology (freq. 2), among others.

Tree

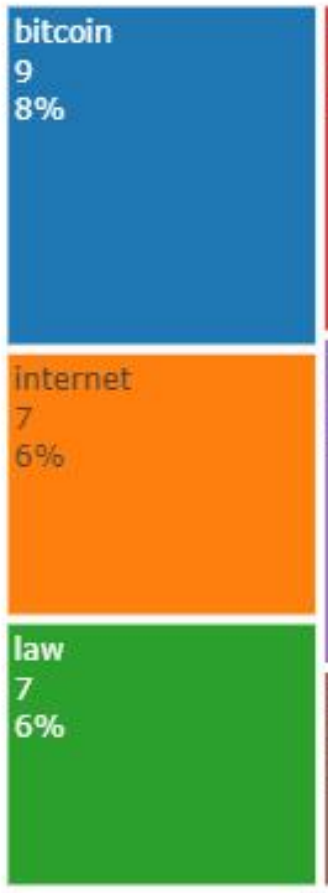

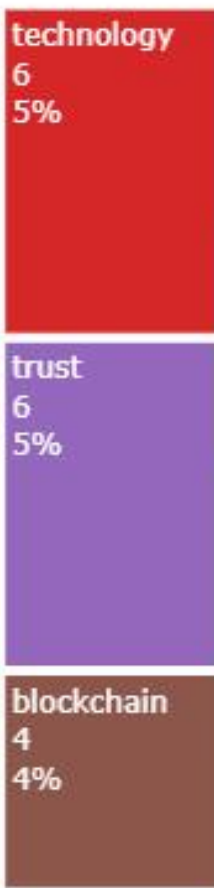

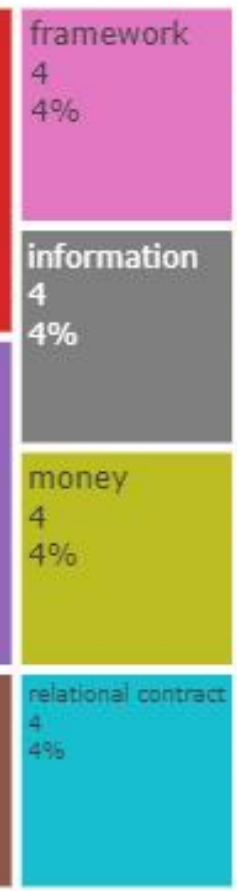

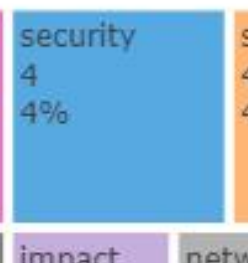
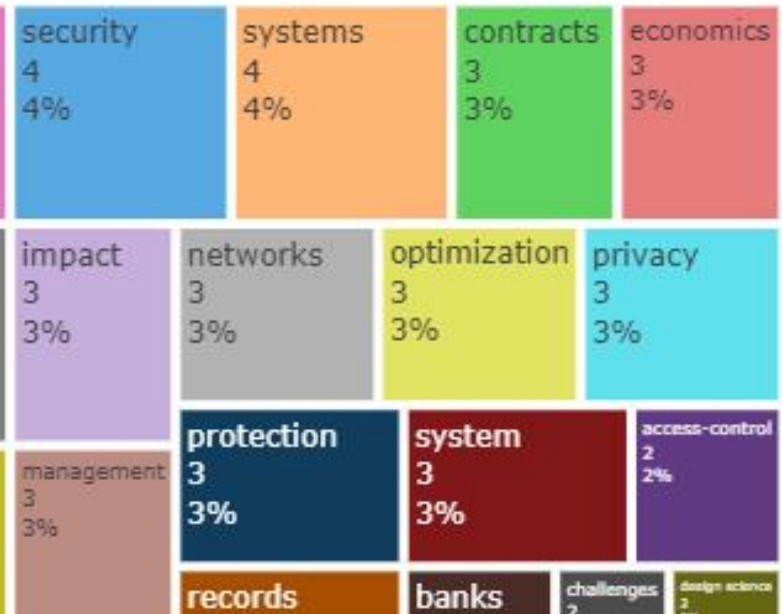

3

$3 \%$

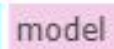

3 $3 \%$

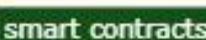

3

$3 \%$

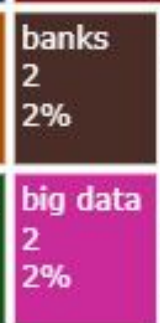

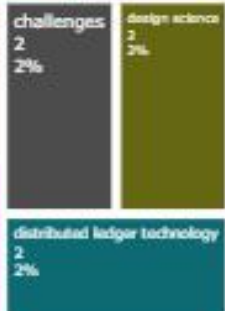

Figure 4. Keyword Plus TreeMap. The number of words (10-30).

\subsection{Thematic Map: Strategic Diagram}

Figure 5 shows the structure of the strategic diagram of the analysis performed. The $x$-axis shows the density, which measures the proportion of relationships present in it concerning the maximum number of relationships that can exist. The density of each group's network varies within a range from 0 to 1 , where a value of zero means that no relationship exists between group members, while a value of one means that all group members are related to each other, being the maximum level of relationship that can exist between group members [47].

The ordinate axis shows centrality, which is the property that identifies the nodes with the highest number of links within a network [47]. More central actors may have an advantageous position concerning others in the sense that they have more alternatives to satisfy their needs, more possibilities of access to resources, and are considered less dependent.

The strategic diagram represents four quadrants 4: Motor Themes; Peripheral and Marginal Themes; Emerging or Disappearing Themes; and Generic and Transversal Themes. 


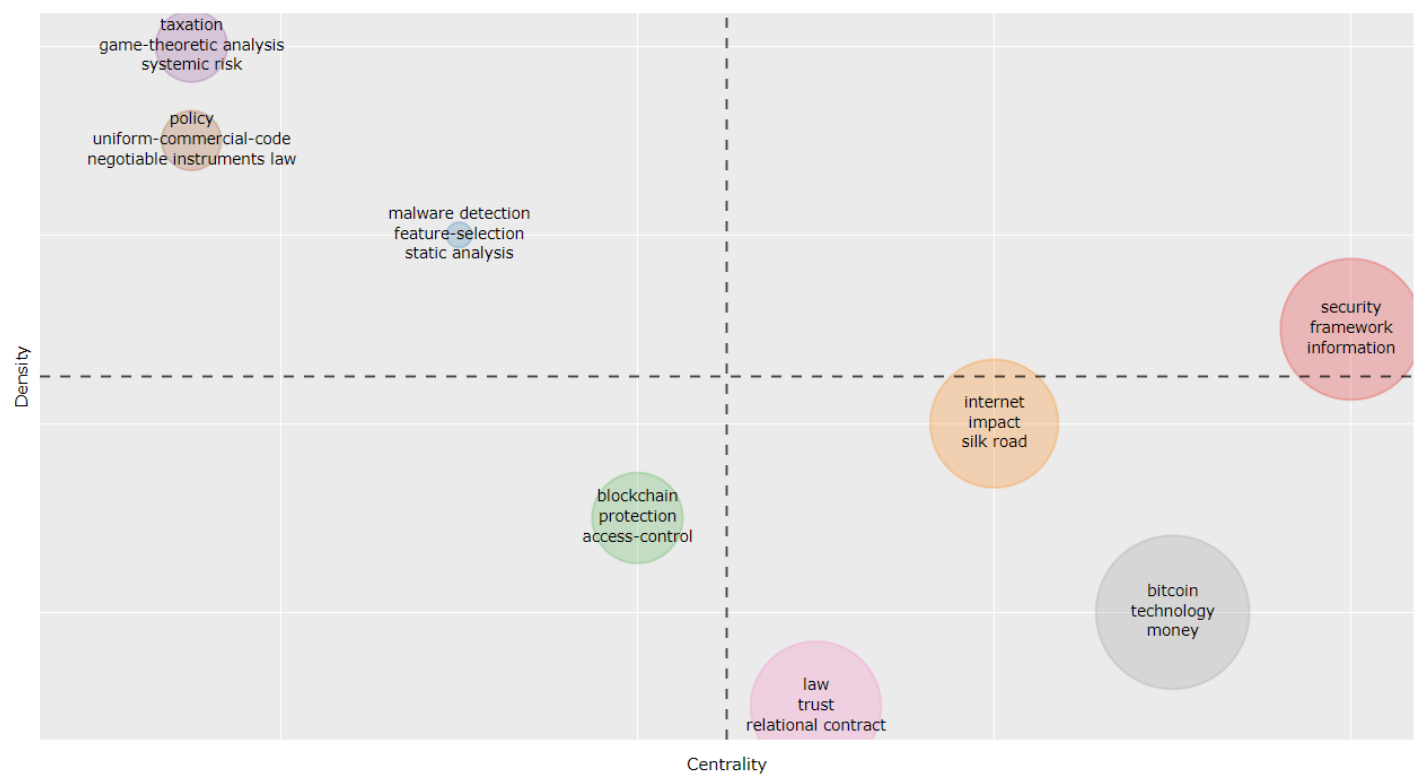

Figure 5. Strategic Diagram. TM Parameters: Field (Keyword Plus), Number of words (50-100), Min Cluster Frequency (1-5), Number of Labels (for each cluster 1-3), Label Size (0-0.2).

- Driving Themes: Represented in the upper right quadrant, driving themes refer to well-developed and important themes. The study has identified a cluster consisting of three sub-themes: security, framework, and information. These themes are of particular importance for the construction of the scientific field due to their strong centrality and high density.

- Peripheral and Marginal Themes: Represented in the upper left quadrant, these themes refer to peripheral and marginal themes. The study has identified three clusters with the following sub-themes: Cluster 1, Taxation, game-theoretical analysis and systemic risk. Cluster 2. Policy, uniform-commercial-code, and negotiable instruments law; Finally, Cluster 3. Malware detection, feature-selection, and static analysis. These topics are well developed internally, however, they are isolated from the rest of the topics, having marginal importance within the scientific field.

- Emerging or Disappearing Themes: Represented in the lower left quadrant, emerging, or disappearing themes refer to underdeveloped themes or in the process of disappearing. The analysis has shown an emerging cluster with three sub-themes: Blockchain, protection and Access-control.

- Generic and Transversal Themes: Represented in the lower right quadrant are the basic and transversal themes of the scientific field analyzed. The analysis has shown three clusters with the following sub-themes: cluster 1 , internet, impact, and silk road; Cluster 2, formed by bitcoin, money, and technology; Finally, Cluster 3, law, trust, and relational contract. These topics are basic and are not well developed, however, they are important for the scientific field.

\subsection{Social Structure: Collaboration Network (Countries)}

Figure 6 shows the social structure represented by a country collaboration network that produces research related to tax regulation on cryptocurrencies and blockchain and the generated collaborative networks. Although many countries publish on the subject, only a small collaboration cluster can be distinguished. The cluster comprises the following countries: USA, United Kingdom, Germany, China, Italy, Australia, The Netherlands, Indonesia, Canada, Switzerland, Greece, and Estonia. The study demonstrates, that despite identifying a significant number of countries working on the studied issues, there is no representative structure of collaboration patterns between them. In this sense, Russia 
stands out as the country with the greatest number of publications in this field, but it does not present collaborations with other countries.

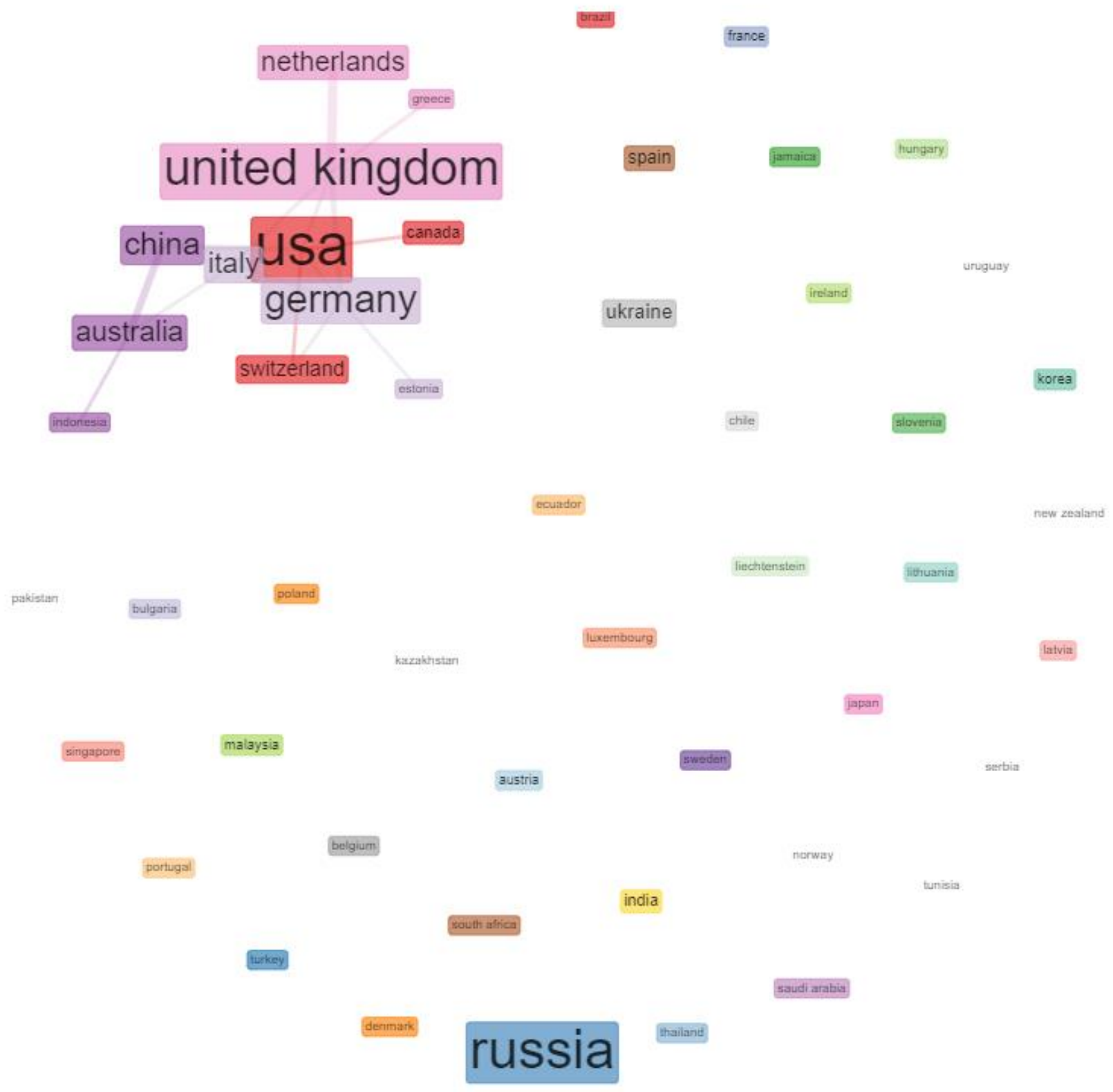

Figure 6. Social structure: collaboration network (countries). Clustering algorithm: Louvain, min edges (2), number of labels (5-50) and number of nodes (5-50).

\section{Discussion: Tax Regulation, Blockchain, Cryptocurrency, and Open Innovation}

\subsection{Discussion: Tax Regulation on Blockchain and Cryptocurrency}

In the present study, a bibliometric analysis of taxation regulation on blockchain and cryptocurrency has been conducted. The review allows us to highlight the following remarkable findings:

- The study has shown a growing interest in this discipline in the last five years, with exponential growth of $116.88 \%$. In recent decades, the development and speed of technological change have increased to levels never imagined, so it is not surprising that there has been a sudden increase in research in this field of knowledge. We can name many other technologies that have followed this exponential growth curve. For 
example, virtual reality (VR), nanotechnology, artificial intelligence (AI), Data Science or robotics, among many others [48,49].

- Computer Law \& Security Review (CLSR) by Elsevier with 15 articles and 197 citations related to tax regulation on blockchain and cryptocurrency is the most relevant source. Edited by Sophie Stalla-Bourdillon, CLSR is an international journal of technology law and practise focused on ePrivacy, e-commerce, outsourcing, EU and public sector ICT policy, security, data protection, cyber-crime, surveillance, intellectual property, security, telecoms regulation, Internet law, and many others. The journal is part of the Journal Citation Report (JCR) and has a Journal Impact Factor (JIF) of 1.849 (2019) and 1.592 (5-year). It should be noted that only $10 \%$ of the journals cited belong to the JCR and $40 \%$ belong to the SJR. The most frequent category is LAW (appearing in a total of 5 sources), followed by BUSINESS, MANAGEMENT AND ACCOUNTING (1 source), COMPUTER NETWORKS AND COMMUNICATIONS (1 source) and SOCIOLOGY AND POLITICAL SCIENCE (1 source). This fact demonstrates the inter-disciplinarity of this field of law (tax regulation in cryptocurrency and blockchain) with other fields of research such as social sciences (sociology and politics), computer science or IT (computer networks and communications).

- The most local cited source is Lecture Notes in Computer Science (LNCS) by Springer with 124 articles cited in the author's references. This distinguished conference proceedings series publishes the latest research and new developments in computer science and information technology research and teaching. The fact of citing so many works of LNCS shows how authors specialized in tax regulation in crypto money and blockchain tend to reference their works mostly with reference from engineering and computer science journals rather than from journals of the social and legal sciences branches. It shows a close link between both branches of knowledge and in this case complimentary since normally researchers in this area usually have a rather hybrid research profile that develops between the different cited areas of knowledge.

- The most relevant author is Professor Alexander Savelyev (3 H-Index papers and 89 citations), Associate Professor at the Faculty of Law/School for Theory of Law, and Cross-sectoral Legal Disciplines at HSE University since 2012 (Moscow, Russian Federation). Professor Savelyev has strong connections with the International Laboratory for IT and IP Law, at HSE University, a forum for discussing prospects for regulation of information security and data protection. Savelyev researches how blockchain technology influences traditional contract law, and he is an expert in issues related to tokenization's risks, "Blockchainzation" of private law, copyright in blockchain, smarts contracts $[3,50,51]$, among others. He also teaches the subjects "Legal Aspects of e-commerce" and "Legal Regime of Personal Data".

- The most relevant affiliation is The Institute of Legislation and Comparative Law under the Government of the Russian Federation. The institute is the oldest centre of Russian legal science (10 Freq. affiliations), established more than 80 years ago, a research organisation incorporated as a federal-state research institution. The director is Professor Taliya Khabriyeva, DSc (Law), a Member of the Russian Academy of Sciences. The Institute includes 17 scientific departments doing research on national legislation and their development tendencies as well as comparative law investigation on the legislation and law enforcement practice of foreign states. It should be noted that Russia has $40 \%$ of the most relevant research affiliations in Blockchain and crypto money tax regulation. However, despite being at the top of the rankings, many of the institutions are not part of the ARWU and QS international rankings of university prestige and quality because they are either not university research institutes, development and innovation centres or government agencies, or private institutions that do not have a university or higher education status and therefore are not included in the rankings or otherwise may not have the quality and characteristics necessary to be included in the various rankings produced by the various assessment bodies. 
- The work of Kshetri [14], "Blockchain's roles in strengthening cybersecurity and protecting privacy" is the most global cited document. This is a renowned and successful work. The manuscript discusses blockchain and cryptocurrency policy implications. According to Kshetri [14], the major findings and challenges proposed in this manuscript are:

(1) To strengthen IoT, regulators can make it obligatory for firms to deploy blockchain in the supply chain, especially in systems that are mission-critical and have substantial national security and economic benefits.

(2) Public policy efforts directed at protecting privacy using blockchain should focus on providing training to key stakeholders and increasing investment in this technology.

(3) To enrich the blockchain ecosystem would be to turn attention to public-private partnerships.

(4) National governments should provide legal clarity and more information for parties to engage in enforceable Smart Contracts.

- Russia is the country with the highest scientific production. Despite having no central hub for crypto and blockchain development and taxation regulation research, Russian researchers have an outsize presence in the world of virtual assets. In addition, this outstanding scientific production in this area may respond to several state investment programs and long-terms blockchain crypto development policy plans [52-54].

- The USA appears to have a distinguished role when observing the universal preference of the authors of the selection of 343 documents once citing their works and referencing the bibliographies. This fact may be due to location, cultural relations, and language when determining factors in shaping preferences whether in co-authorship, crossreference, or cross-citation [55].

- The most frequent associated words were blockchain, law, trust and internet and the words that were least represented were distributed ledger technology and accesscontrol. These results coincide with the work of Yli-Huumo et al. [56] published in PLOS ONE, as their results showed that over $80 \%$ of the papers analysed, focused on Bitcoin system and less than $20 \%$ deals with other blockchain applications including e.g., Smart Contracts, cryptocurrencies and licensing. Most of the research is focusing on revealing and improving the limitations of blockchain from privacy and security perspectives, but many of the proposed solutions lack concrete evaluation on their effectiveness.

- As shown in the strategic diagram, there is a strong relationship between the clusters located on the right side of the figure, due to their level of density. This can be considered normal since the issues they address have a complementary relationship. About centrality, the analysis has shown us, two well-differentiated groups. Firstly, we have a peripheral group with a very high centrality, which indicates that they do not need other topics or clusters to develop. On the other hand, we have five clusters formed by blockchain, internet, security, law, and bitcoin, which have a low centrality, indicating that they are more dependent to develop. This result is complementary to the one obtained in the density analysis since the clusters that have a strong density are those that are more dependent. The analysis has also shown a linear relationship between the clusters represented by blockchain, the internet and security. This relationship is justified since aspects such as security, access control, protection, and the dark internet, are closely related to each other, and are fundamental topics to develop the internet or blockchain. Likewise, the study has shown that there is a growing scientific production in the field of tax regulation in blockchain and cryptocurrency, in the deep internet environment, for example, the illegal sale portal Silk Road. This growing production can be directly related to the interest of researchers and governments in deepening legislation and regulation of virtual currency and taxation. Another aspect of the study that stands out is related to the search for a legislative framework for the regulation of taxes and virtual currency. The results derived may be closely related to the social structure shown in the analysis (a collaboration between countries). The study has shown us that the blockchain, internet, 
security, law, and bitcoin clusters are dependent on each other as they address issues that are complementary and are experiencing similar growth with a tendency to become driving themes.

- The corresponding author's affiliation and the social structure represented in the collaboration network between countries has shown that even though Russia is the country with the highest scientific production, practically all the work it produces is through intra-collaboration, meaning that it does not produce research with authors beyond its borders [57]. The same happens with Ukraine, it has a notorious volume of scientific production, but it does not have inter-collaborations. There is only a cluster of European countries that publish jointly with North America, Indonesia, and China. These patterns of scientific collaboration may be due to linguistic factor and personal preferences, and on many occasions, these patterns of scientific collaboration respond to geopolitical and cultural issues, as well as to conflicts of economic interests. In addition, this could be motivated by an interest in joint research on this topic, since these are countries that may have an interest in establishing a common framework to regulate and legislate on this issue. It is not surprising, therefore, that Slavic countries collaborate more with each other because they share a common bond, which is language in this case [58-60]. Several studies indicate that there is a rather weak scientific collaboration in the fields of social and natural sciences between the countries of the European Union (EU) and Russia. Russia's weak inter-collaboration usually occurs with countries with closer geographical proximity and with traditional connections or historical ties (e.g., Russia and Eastern European countries or relations between Russia and the Baltic states) [61]. Besides, recent research supports the need and development of the legal aspects of international research to ensure the full integration of Russian science into international research activities [62]. For example, in the field of nanotechnology, Russia maintains a network of research links with countries of the former Soviet Union and the Warsaw Pact, carrying out collaborative scientific publications and with a predominance of national over international collaborations [63]. This fact can be closely related to the present study on tax regulation in cryptocurrency and blockchain.

\subsection{Discussion: Tax Regulation on Blockchain and Cryptocurrency, and Open Innovation}

Open innovation proposes an innovation strategy whereby companies go beyond their boundaries and develop cooperation to accelerate and boost corporate innovation capabilities, expanding the possibilities for external use of the resulting projects in different fields [64].

In this new context, blockchain technology is becoming an essential element to empower and support open innovation in numerous aspects:

- Fostering entrepreneurship and innovation. Through the creation of new digital tokens that allow representing different types of assets [65]. In this context, blockchain is the ideal instrument, as it is designed for this, as is the case with virtual currencies.

- As a regulator to balance economies, and favour growth rates. Yun et al. address the growth limits of capitalism, showing that the modern economy can be modelled as a business cyclical dynamic of open innovation with three sub-economies: open market innovation by SMEs and startups; closed open innovation by large firms; and social open innovation [66]. According to these authors, when there is a low equilibrium between the three sub-economies, i.e., if any of the sub-economies is too large or too small, the dynamics of the economy and the rate of economic growth slows down to almost zero or even negative. Conversely, when there is a medium equilibrium between the three sub-economies, i.e., any one of the sub-economies is large enough to lead the total economy but is not large enough to control the other two economies, the dynamics of the economy increases and the economic growth rate will remain at a high level. Among the benefits that blockchain brings to companies, we can find: the reduction of costs and bureaucracy, time savings, transparency, security, tracking of 
stored information, among others. All benefits in themselves, allow companies to be more dynamic and sustainable over time.

- Enhancing the sharing economy. The role of governments and regulars must change to create and maintain innovation ecosystems, moving from a control role to a facilitator role. Blockchain technology is designed for this since its origin is bitcoin, where transactions are facilitated and guaranteed without the need for intermediaries. This last aspect is very important, as it is a way to save time and reduce costs, fundamental aspects of any company [67].

- Securing industrial and intellectual property. One of the main concerns of companies to cooperate in open cooperation processes is the one related to sharing products or services, which is considered risky and uncertain [68]. In this context, blockchain can be a solution to this problem since it allows to ensure the authorship and ownership of any asset, allowing the authentication of the owner through immutability property that owns the chain.

\section{Conclusions}

\subsection{Implications}

This study has shown the lack of collaboration between countries, which may be produced because this is a discipline that is still day-by-day being implemented, although there could be other aspects, such as the lack of international legal and fiscal harmonization to be able to operate with this new technology among the different research scenarios.

\subsection{Limitations and Future Research Lines}

Identifying and studying international scientific collaboration could be of great interest for future research work as well as exploring scientific production through comparative studies or alternative indicators such as altmetrics [69], among others. In addition, it would be interesting to deepen at the scientometric level the research on tax regulation in blockchain and cryptocurrency and open innovation and its relationship and implication with entrepreneurship and innovation, the balance of economies, sharing economy, and industrial and intellectual property, among others.

Author Contributions: Conceptualization, A.P.-R., P.S.-N. and Y.G.C.; methodology, P.S.-N.; software, P.S.-N.; validation, A.P.-R., and P.S.-N.; formal analysis, A.P.-R. and P.S.-N.; investigation, A.P.-R., P.S.-N. and Y.G.C.; resources, P.S.-N.; data curation, P.S.-N.; writing—original draft preparation, A.P.R., and P.S.-N.; writing—review and editing, A.P.-R. and P.S.-N.; visualization, P.S.-N.; supervision, Y.G.C.; project administration, Y.G.C. All authors have read and agreed to the published version of the manuscript.

Funding: This research received no external funding.

Data Availability Statement: The data presented in this study are openly available in Zenodo repository: https:/ / doi.org/10.5281/zenodo.4568216 (accessed date 16 March 2021) [33].

Acknowledgments: Not applicable.

Conflicts of Interest: The authors declare no conflict of interest.

\section{References}

1. Lewis, R.; McPartland, J.; Ranjan, R.; Lewis, R.; McPartland, J. Blockchain and Financial Market Innovation. Econ. Perspect. 2017, 7, 2-12.

2. Böhme, R.; Christin, N.; Edelman, B.; Moore, T. Bitcoin: Economics, Technology, and Governance. J. Econ. Perspect. 2015, 29, 213-238. [CrossRef]

3. Savelyev, A. Legal aspects of ownership in modified open source software and its impact on Russian software import substitution policy. Comput. Law Secur. Rev. 2017, 33, 193-210. [CrossRef]

4. Gai, K.; Qiu, M.; Sun, X. A survey on FinTech. J. Netw. Comput. Appl. 2018, 103, 262-273. [CrossRef]

5. Huckle, S.; Bhattacharya, R.; White, M.; Beloff, N. Internet of Things, Blockchain and Shared Economy Applications. Procedia Comput. Sci. 2016, 98, 461-466. [CrossRef] 
6. Christidis, K.; Devetsikiotis, M. Blockchains and Smart Contracts for the Internet of Things. IEEE Access 2016, 4, $2292-2303$. [CrossRef]

7. Liu, Y.; He, D.; Obaidat, M.S.; Kumar, N.; Khan, M.K.; Raymond Choo, K.-K. Blockchain-based identity management systems: A review. J. Netw. Comput. Appl. 2020, 166, 102731. [CrossRef]

8. Nofer, M.; Gomber, P.; Hinz, O.; Schiereck, D. Blockchain. Bus. Inf. Syst. Eng. 2017, 59, 183-187. [CrossRef]

9. Sullivan, C.; Burger, E. E-residency and blockchain. Comput. Law Secur. Rev. 2017, 33, 470-481. [CrossRef]

10. Chan, S.; Chu, J.; Zhang, Y.; Nadarajah, S. Blockchain and Cryptocurrencies. J. Risk Financ. Manag. 2020, 13, 227. [CrossRef]

11. Legerén-Molina, A. Los contratos inteligentes en España. La disciplina de los Smart Contracts. Rev. Derecho Civ. 2018, 5, 193-241.

12. Mikhaylov, A. Cryptocurrency Market Analysis from the Open Innovation Perspective. J. Open Innov. Technol. Mark. Complex. 2020, 6, 197. [CrossRef]

13. Wang, S.; Ouyang, L.; Yuan, Y.; Ni, X.; Han, X.; Wang, F.-Y.Y. Blockchain-Enabled Smart Contracts: Architecture, Applications, and Future Trends. IEEE Trans. Syst. Man Cybern. Syst. 2019, 49, 2266-2277. [CrossRef]

14. Kshetri, N. Blockchain's roles in strengthening cybersecurity and protecting privacy. Telecomm. Policy 2017, 41, 1027-1038. [CrossRef]

15. Boucher, P.; Nascimento, S.; Kritikos, M. How Blockchain Technology Could Change Our Lives. Eur. Parliam. 2017, 4-25. [CrossRef]

16. Bogers, M.; Chesbrough, H.; Moedas, C. Open Innovation: Research, Practices, and Policies. Calif. Manag. Rev. 2018, 60, 5-16. [CrossRef]

17. Cano, J.A.; Londoño-Pineda, A. Scientific Literature Analysis on Sustainability with the Implication of Open Innovation. J. Open Innov. Technol. Mark. Complex. 2020, 6, 162. [CrossRef]

18. Yun, Y.; Lee, M. Smart City 4.0 from the Perspective of Open Innovation. J. Open Innov. Technol. Mark. Complex. 2019, 5, 92. [CrossRef]

19. Kosmarski, A. Blockchain Adoption in Academia: Promises and Challenges. J. Open Innov. Technol. Mark. Complex. 2020, 6, 117. [CrossRef]

20. Zhao, J.L.; Fan, S.; Yan, J. Overview of business innovations and research opportunities in blockchain and introduction to the special issue. Financ. Innov. 2016, 2, 28. [CrossRef]

21. Legerén-Molina, A. Retos Jurídicos Que Plantea La Tecnología De La Cadena De Bloques. Aspectos Legales De Blockchain. Rev. Derecho Civ. 2019, VI, 177-237.

22. Setyowati, M.S.; Utami, N.D.; Saragih, A.H.; Hendrawan, A. Blockchain Technology Application for Value-Added Tax Systems. J Open Innov. Technol. Mark. Complex. 2020, 6, 156. [CrossRef]

23. Dabbagh, M.; Sookhak, M.; Safa, N.S. The Evolution of Blockchain: A Bibliometric Study. IEEE Access 2019, 7, $19212-19221$. [CrossRef]

24. Duquenne, M.; Prost, H.; Schöpfel, J.; Dumeignil, F. Open Bioeconomy-A Bibliometric Study on the Accessibility of Articles in the Field of Bioeconomy. Publications 2020, 8, 55. [CrossRef]

25. Firdaus, A.; Razak, M.F.A.; Feizollah, A.; Hashem, I.A.T.; Hazim, M.; Anuar, N.B. The rise of "blockchain": Bibliometric analysis of blockchain study. Scientometrics 2019, 120, 1289-1331. [CrossRef]

26. Guo, X.; Donev, P. Bibliometrics and Network Analysis of Cryptocurrency Research. J. Syst. Sci. Complex. 2020. [CrossRef]

27. Jiang, S.; Li, X.; Wang, S. Exploring evolution trends in cryptocurrency study: From underlying technology to economic applications. Financ. Res. Lett. 2020, 101532. [CrossRef]

28. Miau, S.; Yang, J.-M. Bibliometrics-based evaluation of the Blockchain research trend: 2008-March 2017. Technol. Anal. Strateg. Manag. 2018, 30, 1029-1045. [CrossRef]

29. Sanchez-Nunez, P.; Cobo, M.J.; Las Heras-Pedrosa, C.D.; Pelaez, J.I.; Herrera-Viedma, E.; de las Heras-Pedrosa, C.; Pelaez, J.I.; Herrera-Viedma, E. Opinion Mining, Sentiment Analysis and Emotion Understanding in Advertising: A Bibliometric Analysis. IEEE Access 2020, 8, 134563-134576. [CrossRef]

30. Montero Díaz, J.; Cobo, M.; Gutiérrez, M.; Segado Boj, F.; Herrera Viedma, E. Mapeo científico de la Categoría «Comunicación» en WoS (1980-2013). Comun. Rev. Científica Iberoam. Comun. y Educ. 2018, 81-91. [CrossRef]

31. Perez-Cabezas, V.; Ruiz-Molinero, C.; Carmona-Barrientos, I.; Herrera-Viedma, E.; Cobo, M.J.; Moral-Munoz, J.A. Highly cited papers in rheumatology: Identification and conceptual analysis. Scientometrics 2018, 116, 555-568. [CrossRef]

32. Aria, M.; Cuccurullo, C. bibliometrix: An R-tool for comprehensive science mapping analysis. J. Informetr. 2017, 11, 959-975. [CrossRef]

33. Peláez-Repiso, A.; Sánchez-Núñez, P.; Calvente, Y.G. Tax Regulation on Blockchain and Cryptocurrency: The Implications for Open Innovation (Citation Report and WoS Dataset). Zenodo 2021. [CrossRef]

34. Aria, M.; Misuraca, M.; Spano, M. Mapping the Evolution of Social Research and Data Science on 30 Years of Social Indicators Research. Soc. Indic. Res. 2020, 149, 803-831. [CrossRef]

35. Agostino, Í.R.S.; Ristow, C.; Frazzon, E.M.; Taboada Rodriguez, C.M. Perspectives on the Application of Internet of Things in Logistics. In International Conference on Dynamics in Logistics; Springer: Cham, Switzerland, 2020; pp. 387-397. [CrossRef]

36. Di Zeo-Sánchez, D.E.; Sánchez-Núñez, P.; Stephens, C.; Lucena, M.I. Characterizing Highly Cited Papers in Mass Cytometry through H-Classics. Biology 2021, 10, 104. [CrossRef] [PubMed] 
37. Alonso, J.M.; Castiello, C.; Mencar, C. A Bibliometric Analysis of the Explainable Artificial Intelligence Research Field. In International Conference on Information Processing and Management of Uncertainty in Knowledge-Based Systems; Springer: Cham, Switzerland, 2018; pp. 3-15. [CrossRef]

38. Hirsch, J.E. An index to quantify an individual's scientific research output. Proc. Natl. Acad. Sci. USA 2005, 102, 16569-16572. [CrossRef] [PubMed]

39. Marginson, S. University Rankings and Social Science. Eur. J. Educ. 2014, 49, 45-59. [CrossRef]

40. Mattsson, P.; Sundberg, C.J.; Laget, P. Is correspondence reflected in the author position? A bibliometric study of the relation between corresponding author and byline position. Scientometrics 2011, 87, 99-105. [CrossRef]

41. Kiviat, T.I. Beyond Bitcoin: Issues in regulating blockchain transactions. Duke Law J. 2015, 65, 569-608.

42. Werbach, K.; Cornell, N. Contracts ex machina. Duke Law J. 2017, 67, 313-382.

43. Savelyev, A. Some risks of tokenization and blockchainizaition of private law. Comput. Law Secur. Rev. 2018, 34, 863-869. [CrossRef]

44. Turk, Ž.; Klinc, R. Potentials of Blockchain Technology for Construction Management. Procedia Eng. 2017, 196, 638-645. [CrossRef]

45. Alferes, J.J.; Bertossi, L.; Governatori, G.; Fodor, P.; Roman, D. (Eds.) Rule Technologies. Research, Tools, and Applications; Lecture Notes in Computer Science; Springer International Publishing: Cham, Switzerland, 2016; Volume 9718. [CrossRef]

46. Truby, J. Decarbonizing Bitcoin: Law and policy choices for reducing the energy consumption of Blockchain technologies and digital currencies. Energy Res. Soc. Sci. 2018, 44, 399-410. [CrossRef]

47. Wasserman, S.; Faust, K. Social Network Analysis; Cambridge University Press: Cambrigde, UK, $1994 ;$ ISBN 9780521387071.

48. Tague, J.; Beheshti, J.; Rees-Potter, L. The law of exponential growth: Evidence, implications and forecasts. Libr. Trends 1981, 30, $125-145$.

49. Taylor, P.J.; Dargahi, T.; Dehghantanha, A.; Parizi, R.M.; Choo, K.-K.R. A systematic literature review of blockchain cyber security. Digit. Commun. Networks 2020, 6, 147-156. [CrossRef]

50. Savelyev, A. Contract law 2.0: 'Smart' contracts as the beginning of the end of classic contract law. Inf. Commun. Technol. Law 2017, 26, 116-134. [CrossRef]

51. Savelyev, A. Copyright in the blockchain era: Promises and challenges. Comput. Law Secur. Rev. 2018, 34, 550-561. [CrossRef]

52. Nazarov, A.D.; Shvedov, V.V.; Sulimin, V.V. Blockchain technology and smart contracts in the agro-industrial complex of Russia. IOP Conf. Ser. Earth Environ. Sci. 2019, 315, 032016. [CrossRef]

53. Vovchenko, N.G.; Andreeva, A.V.; Orobinskiy, A.S.; Filippov, Y.M. Competitive Advantages of Financial Transactions on the Basis of the Blockchain Technology in Digital Economy. Eur. Res. Stud. J. 2017, XX, 193-212. [CrossRef]

54. Zharova, A.; Lloyd, I. An examination of the experience of cryptocurrency use in Russia. In search of better practice. Comput. Law Secur. Rev. 2018, 34, 1300-1313. [CrossRef]

55. Schubert, A.; Glänzel, W. Cross-national preference in co-authorship, references and citations. Scientometrics 2006, 69, 409-428. [CrossRef]

56. Yli-Huumo, J.; Ko, D.; Choi, S.; Park, S.; Smolander, K. Where Is Current Research on Blockchain Technology?-A Systematic Review. PLoS ONE 2016, 11, e0163477. [CrossRef] [PubMed]

57. Grácio, M.C.C.; De Oliveira, E.F.T.; Chinchilla-Rodríguez, Z.; Moed, H.F. The influence of corresponding authorship on the impact of collaborative publications: A study on Brazilian institutions (2003-2015). In Proceedings of the 17th International Conference on Scientometrics and Informetrics, ISSI 2019-Proceedings, Rome, Italy, 2-5 September 2019; International Society for Scientometrics and Informetrics: Leuven, Belgium, 2019; Volume 1, pp. 511-522.

58. Chinchilla-Rodríguez, Z.; Benavent-Pérez, M.; de Moya-Anegón, F.; Miguel, S. International collaboration in Medical Research in Latin America and the Caribbean (2003-2007). J. Am. Soc. Inf. Sci. Technol. 2012, 63, 2223-2238. [CrossRef]

59. Luukkonen, T.; Persson, O.; Sivertsen, G. Understanding Patterns of International Scientific Collaboration. Sci. Technol. Hum. Values 1992, 17, 101-126. [CrossRef]

60. Scarazzati, S.; Wang, L. The effect of collaborations on scientific research output: The case of nanoscience in Chinese regions. Scientometrics 2019, 121, 839-868. [CrossRef]

61. Marshakova-Shaikevich, I.V. Scientific collaboration between Russia and the EU countries: A bibliometric analysis. Her. Russ. Acad. Sci. 2010, 80, 57-62. [CrossRef]

62. Avanesova, A.A.; Shamliyan, T.A. Comparative trends in research performance of the Russian universities. Scientometrics 2018, 116, 2019-2052. [CrossRef]

63. Karaulova, M.; Gök, A.; Shackleton, O.; Shapira, P. Science system path-dependencies and their influences: Nanotechnology research in Russia. Scientometrics 2016, 107, 645-670. [CrossRef]

64. Yun, J.J.; Kim, D.; Yan, M.-R. Open Innovation Engineering-Preliminary Study on New Entrance of Technology to Market. Electronics 2020, 9, 791. [CrossRef]

65. Chen, Y. Blockchain tokens and the potential democratization of entrepreneurship and innovation. Bus. Horiz. 2018, 61, 567-575. [CrossRef]

66. Yun, J.J.; Won, D.; Park, K. Entrepreneurial cyclical dynamics of open innovation. J. Evol. Econ. 2018, 28, 1151-1174. [CrossRef]

67. Yun, J.J.; Liu, Z. Micro- and Macro-Dynamics of Open Innovation with a Quadruple-Helix Model. Sustainability 2019, 11, 3301. [CrossRef] 
68. Maicher, L.; Gibovic, D.; de la Rosa, J.L.; Torres-Padrosa, V. On Intellectual Property in Online Open Innovation for SME by means of Blockchain and Smart Contracts. In Proceedings of the World Open Innovation Conference 2016 (WOIC2016), Barcelona, Spain, 15-16 December 2016; Garwood Center for Corporate Innovation: Barcelona, Spain, 2016.

69. Torres-salinas, D.; Group, S.C.; Researcher, C.; Jim, E. Altmetrics: New indicators for scientific communication in Web 2.0. Comunicar 2015, 2013, 1-9. [CrossRef] 